\title{
RUANG TEMPORER SOSIAL SEBAGAI SALAH SATU BENTUK RUANG SOSIAL DAN ASPIRASI MASYARAKAT DALAM PEMENUHAN KEBUTUHAN RUANG PUBLIK KOTA
}

\author{
Ghoustanjiwani Adi Putra \\ Dosen Prodi Arsitektur, Fak. Teknik Sipil dan Perencanaan, ITN Malang \\ e-mail: ghoustanputra@lecturer.itn.ac.id \\ Daim Triwahyono \\ Dosen Prodi Arsitektur, Fak. Teknik Sipil dan Perencanaan, ITN Malang \\ e-mail: daimtriwahyono@lecturer.itn.ac.id
}

\begin{abstract}
ABSTRAK
Ruang temporer sosial dipahami sebagai ruang publik yang terbentuk dari proses sosial. Dalam (Lefebvre 2000) "production of space" ruang sosoal digambarkan kedalam bentuk ruang yang terstruktur dari waktu (Time). Pada studi kasus terpilih yaitu: Festival kampung sedjarah Tawangsari, penulis melakukan kajian evaluasi secara deskriptif dari kajian literatur dan hasil penelitian terkait. Penulis menemukan bahwa ruang sosial temporer pada studi kasus dipengaruhi oleh 3 faktor jaringan pembentuk antara lain: Ikatan Antar aktor pembentuk yang simetris, ikatan antar individu aktor pada jaringan masyarakat yang lebih luas dan adanya struktur ikatan sosial yang terhubung .
\end{abstract}

Kata kunci : Ruang Publik, Ruang sosial, Ruang Temporer

\begin{abstract}
Social temporary space is understood as public space that is formed by social processes. In (Lefebvre 2000) "production of space" social space is depicted in the form of space that structured from time. From the selected case study: Tawangsari festival, the authors conducted from descriptive analysis and literature review. The author found that the temporary social space in the case study influenced by 3 factors: a symmetrical Formation Between the Actors, bonding from an individual actors in wider community networks and the existence of connected social bond structures.
\end{abstract}

Keywords : Public space, Social space, Temporary space

\section{PENDAHULUAN}

Manusia adalah makhluk sosial dan ruang publik selalu menjadi arena panggung interaksi, sosialisasi dan representasi masyarakat serta budaya yang mewadahi arena sosial dari manusia (Carmona, Heath, Oc, \& Tiesdell, 
2010). Peran dari ruang publik telah berubah mengikuti sepanjang sejarah dan beradaban pada zaman sejarah itu berlangsung. Perubahan besar yang dialami kota selama berbagai sejarah yang telah berlangsung seperti industri dan teknologi nmyatanya mampu mengubah cara orang mengakses dan terlibat dalam ruang publik (Gehl, 2010). Sebagai contoh adalah adanya berbagai aktifitas-aktifitas baru yang bersifat sementara contoh: promosi marketing kendaraan bermotor dan pusat komersial, sikrus keliling, parade band festival, dan berberapa kegiatan berbasis sosial yang bersifat sementara waktu merupakan konsumsi massal dari fungsi publik yang bersifat publik sebagai tipe ruang publik baru yang berbasis sosial. Baru-baru ini, pada awal revolusi digital, beberapa analis memperkirakan bahwa teknologi informasi akan mengalami disfungsi ruang pada ruang publik. Sebagai contohnya pada pengenalan teknologi seluler, teknologi ini dinilai tidak mendorong kebangkitan masyarakat dalam bersosialisasi dalam ruang publik secara nyata (Foth, 2011). Cara warga bersosialisai dengan dominasi publik kini sangat berbeda. Peran ruang publik sosial secara tradisional (alun-alun, jalan, taman, mall, klub buku, pasar dll), sebagai pertemuan dan tempat sosial telah bergeser diberbagai fungsi, fisik, kegunaan dan interaksi. Jenis ruang publik baru ruang juga muncul karena revolusi digital. Di era industri 4.0 inilah ruang publik memiliki pergeseran yang sangat menyimpang baik dari segi Arti (Meaning) dan kaidah fungsi ruang publik seperti interaksi sosial hanya dilakukan sebatas dunia maya. Jejaring sosial digital merupakan salah satu wujud hilangnya arti (meaning) dari ruang publik yang sesungguhnya.

\section{TINJAUAN PUSTAKA.}

Ruang Publik, Menurut Carr bahwa ruang publik adalah suatu tempat dimana terjadinya kehidupan secara bersama. Jalan, lapangan, dan taman kota ikut (Carr, 1992). Rob Krier, mengartikan ruang publik suatu ruang yang berada diantara bangunan-bangunan perkotaan maupun daerah. Disini Krier lebih senang menyebutkan ruang publik sebagai ruang kota (Krier, 1979). Menurut Rustam Hakim dalam Dedi Hantono (2013) ruang publik adalah ruang yang terbentuk ditimbulkan adanya kebutuhan perlunya suatu media dalam bentuk ruang maupun tempat untuk bertemu dan berkomunikasi antar satu manusia dengan manusia lainnya (Hantono, 2013).

Ruang terbuka publik, adalah ruang terbuka yang dapat diakses secara bebas dan spontan oleh umum. Aksesbilitas ini baik secara visual non visual maupun fisik dan non fisik. Ruang terbuka publik dapat digunakan oleh semua orang dan itu mengandung unsur kegiatan manusia, seperti bermain, berjalan, dan olahraga. Stephen Carr memberikan klasifikasi ruang publik menjadi beberapa jenis berdasarkan kepentingan ruang publik tersebut, yaitu:

- Untuk memberi makna atau signifikansi kepada masyarakat lokal secara individu atau kelompok (bermakna), 
- Agar responsif terhadap semua keinginan pengguna dan dapat mengakomodasi aktivitas yang ada di ruang publik (responsif),

- Untuk menerima kehadiran berbagai lapisan masyarakat bebas tanpa diskriminasi (demokratis).

Ruang Temporer Sosial. Ruang ini dapat dipahami sebagai: Penggunaan lahan "landuse" sementara yang ada di kota-kota. Contoh dari jenis ruang-ruang ini antara lain: mulai dari sirkus dan berbagai festival publik hingga penyimpanan material pada bangunan dan parkir mobil pada lajur sepanjang jalan. Tetapi sampai saat ini, penggunaan ruang tersebut dimanfaatkan untuk transformasi distrik perkotaan disinvestasikan. Mereka adalah epifenomena yang tidak pernah dilihat sebagai bagian dari perencanaan pembangunan kota yang telah direncanakan oleh perencana dan pembangun kebijakan tata kota. Dua studi di Eropa dalam (Bürgin dan Cabane, 1999; Urban Catalyst, 2001) memprakarsai adanya gagasan pemikiran perencanaan dan penelitian pada ranah kajian baru dengan mendefinisikan penggunaan ruang sementara ini ke dalam hal kegiatankegiatan marjinal ekonomi lemah. Kegiatan marjinal ekonomi lemah itu sementara waktu menempati dan mengubah ruang-ruang baik prifat maupun publik perkotaan yang sudah terbengkalai. Mereka akan menggunalkan ruang ini untuk membentuk kegiatan ekonomi dan struktur sosial baru kedalam bentuk ruang-ruang baru yang bersifat dinamis dan sementara. Studi-studi baru pada ruang temporer sosial ini tampaknya telah memperkenalkan setidaknya ada empat titik fokus baru merencanakan pemikiran tentang terbentuknya ruang sementara. Ke empat titik fokus ini antara lain:

- Pertama, penggunaan kembali dianggap sebagai strategi ekonomi dan perencanaan yang penting untuk pembangunan kembali bekasarea yang tidak produktif; untuk kegiatan ruang spasial yang bersifat temporer tersebut.

- Kedua, aktor dari 'industri kreatif' sekarang dipahami sebagai pemain peran penting dalam melakukan penggunaan dan transformasi sementara ini.

- Ketiga, sementara penggunaan situs diakui oleh pemerintah kota sebagai peluang penting untuk menarik dan memelihara industri kreatif.

- Keempat, kebijakan perencanaan, yang secara tradisional berfokus pada visi jangka panjang dan aturan permanen, mulai mencari cara untuk mendukung dan mempromosikan penggunaan jangka pendek tertentu sebagai mekanisme untuk mendorong perubahan kota. 


\section{Ruang Temporer Sosial Sebagai Paradoks pada ruang publik terbuka}

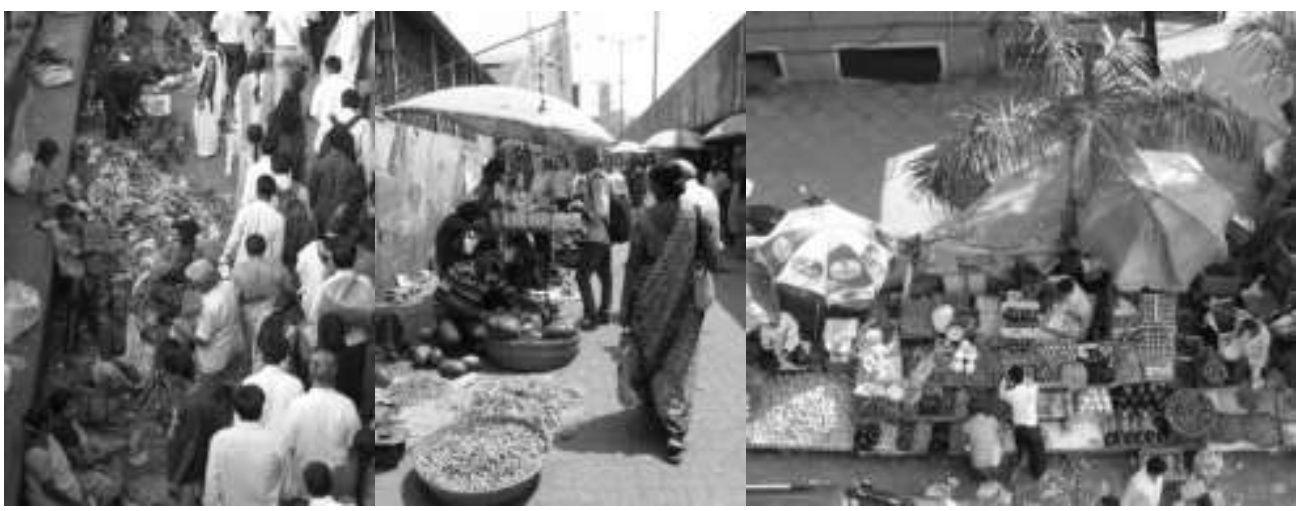

Gambar. 1

Ruang Temporer Sosial Informal

Sumber: (lola Sales, 2018)

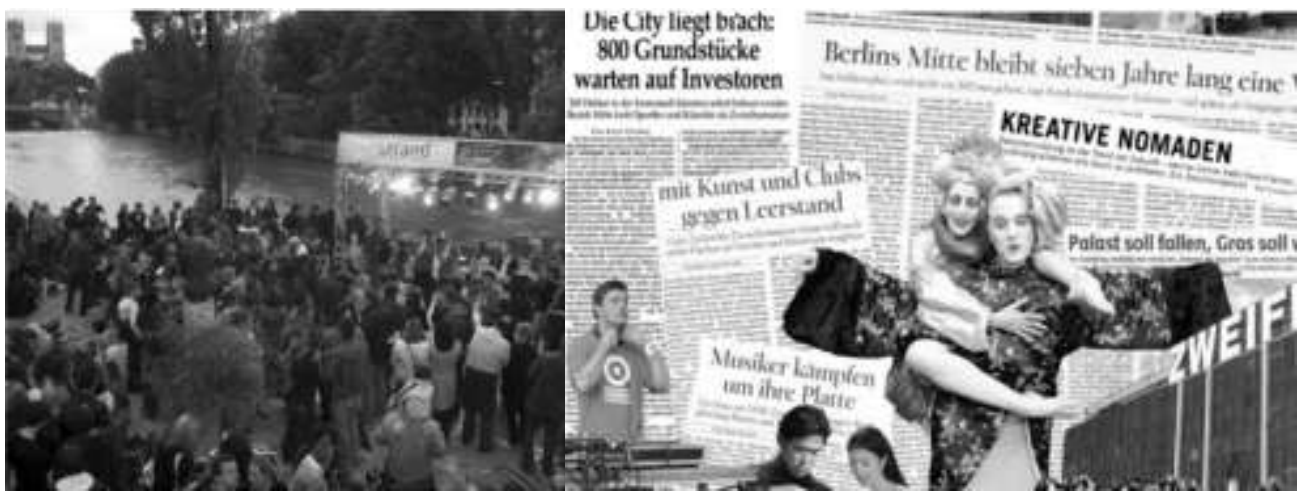

Gambar. 2

Ruang Temporer Sosial formal

Sumber: (urban catalyst dalam steven 2018)

The Street Vendors, Mumbai. (Gambar 1) ruang temporer sosial pada sepanjang jalur publik di Mumbai, India. Sebagai negara dunia ke-3 dan negra berkembang India merupakan negara dengan tingkat urbanisasi yang tinggi. Tingginya tingkat urbanisasi ini membuat kenaikan tingkat jumlah penduduk yang pesat di ikuti tingginya kebutuhan ruang publik. Berbagai bentuk ruang temporer terbentuk di berbagai sisi ruang publik nya, tentunya hal ini sangat bertentangan dengan rencana tata kota yang telah dirancang oleh perencana dan pemangku kebijakan. 
Kulturstrand, Munich. Festival temporer beach pada dermaga jembata Cornelius," (Gambar 2, kanan dan kiri) pada ruang (space) dan yang pada akhirnya menjadi tempat (place) dimana ruang publik menjadi festival temporer yang terbentuk secara legal dan melalui perijinan dari pihak berwenang, oleh karena itu temporal spasial ini bersifat formal. Sedangkan menurut Pogoreutz dan Errisman ruang temporer sosial dapat digambarakan dalam pendapat sebagai berikut:

"informal, spontaneous [temporary uses]... whose primary characteristic is the use of available urban, programmatic, economic open spaces... also have other features that make them perfectly compatible with the neo-liberal economy, from shifting risk to individuals to accelerating the use of space." (Pogoreutz, 2006:79)

Persons engaged in the cultural sector and temporary users coincide with the current principle of short, fast utilisation cycles... the frameworks of both temporary use and subculture activities demand the same characteristics as contemporary entrepreneurial thinking: flexibility, cost-consciousness, environmental friendliness, efficiency, innovation, contemporary thinking, connectedness and liberality. (Erismann, 2011:23)

Florian Haydn dan Robert Temel mengungkapkan proses terbentuknya ruang (space) maupun tempat (place) secara sementara tersebut dapat menghasilkan interaksi sosial yang berbeda, dinamis dan bertautan satusama lain namun masih dalam batasan waktu tertentu. Dalam terbentuknya ruang (space) yang bersifat sementara ini pun mampu berkemebang secara dinamis, mereka berpeluang untuk mengembangkan ruang (space) hingga menghadirkan tempat (place) dengan makna lain dan membawa komunitas komunitas mereka merasa lebih dekat dan solid. Dengan stimulasi jaringan sosial dan keragaman pengalaman setiap individu dalam komunitas tersebut dapat menciptakan kegiatan urban yang berbeda, yang mempengaruhi identitas dan vitalitas kota yang berbeda.

Bill Hillier (2007) mengungkap makna konfigurasi sebagai konsep yang merujuk pada semua hal yang lebih kompleks dari sebuah bagian. Menurut haydn dan temel semua ruang (space) maupun tempat (place) yang terbentuk sementara (temporer) biasanya terbentuk secara tidak legal secara hukum (informal) dan dikendalikan oleh perizinan suatu penguasa wilayah tertentu diluar peraturan perencana dan kebijakan daerah secara legal (Haydn dan Temel, 2006).

Jika kita menetapkan hubungan spasial sebagai sesuatu yang hadir ketika akan ada banyak tipe mata rantai yang menghubungkan satu sama lain sehingga menjadi suatu hal yang dekat dan dapat ditembus antara dua ruang atau lebih dan konfigurasi diantara dua ruang akan diubah berdasarkan pada bagaimana kita menghubungkan satu dengan yang lainnya.

PAWON: Jurnal Arsitektur, Nomor 01 Volume IV, Bulan Januari-Juni Tahun 2020, ISSN 2597-7636 
Dengan analisis ruang dan fungsi dalam konfigurasi serta hubungannya terhadap bangunan kita dapat menemukan pola-pola umum di seluruh sampel, kita dapat melihat bagaimana bangunan dapat menunjukan kecenderungan ke arah budaya dalam bentukan ruang. Hal ini terbiasa dilakukan dengan menyatukan beberapa representasi misalnya dengan meletakkan satu representasi di atas yang lain dan memperhatikan hubungan dalam sistem yang terjadi.

Waktu Sebagai Pengendali Ruang. Waktu (Time) adalah salah satu konsep dasar fundamental dalam teori keberadaan Wujud (Being). Levebfre mengunggkap selain ruang (Space) dan aktivitas manusia (Social), Waktu (Time) memberikan kontribusi yang dinamis dalam sebuah keberadaan (Being). Selain itu Perubahan dan kontinuitas (Morfologi) adalah unsur penting dari keberadaan. Dengan kata lain waktu adalah gagasan konstruksi yang digunakan untuk memberi makna dalam kehidupan di dunia. Manusia tidak bisa dilepaskan dari zaman karena perjalanan hidup manusia adalah dengan perjalanan waktu itu sendiri. Beberapa pendekatan saat ini mengkonseptualisasikan ruang dan waktu sebagai aspek yang tidak terpisah satu sama lain.

Waktu dan ruang dibangun sebagai pengendali ruang dalam proses sosial yang saling terikat satu sama lain. Sebuah konteks yang dimaksudkan sebagai tempat di mana aktivitas manusia menyajikan pengaturan semuanya adalah upaya dalam waktu dan ruang, keterkaitan struktur spasial dan temporal hadir di tempat dan waktu. Jika dilihat dengan cara itu, ruang tidak dapat dianggap sebagai sesuatu yang statis, serta membayangkan waktu tanpa ruang (John Scot, 2011).

Dalam wujud dan waktu, Martin Heidgger (1985) mengungkapkan makna "wujud" atau "being" didefinisikan berdasarkan waktu (temporalitas) dan analisis waktu sebagai cakrawala untuk pemahaman wujud. Heidgger menyajikan pandangannya tentang filsafat sebagai ontologi fenomenologis. Dia hadir sebagai dasar keberadaan, kesadaran yang bisa memahami keberadaan pada hal-hal lain.

Suatu hal yang dapat kita sadari adalah asumsi kita karena kita belum pernah mengalami fase ketika sesuatu yang belum pernah terjadi sebelumnya bahkan tidak terbayangkan dengan kondisinya ketika dia hadir di sekitar kita. Heidgger juga membahas temporaritas sebagai korelasi antara waktu dan ruang.

Ketika kedalam melihat ke dalam ruangan real "fisik", visual, dan kita mampu melakukan analisis kehadiran ruang tersebut baik dengan rentang waktu sementara. Acuan waktu pada batas dan bersifat spatial-temporal seperti inilah yang bisa disebut ruang spasial yang bersifat sementara dan akan berubah sacara dinamis. 
Ada titik di mana saat ruang ini terbentuk, berfungsi dan berakhir. Proses spasialitas adalah kehadiran yang mungkin merupakan satu-satunya yang memulai terbentuknya ruang ini, tidak dapat mendeduksi ruang waktu atau mengakhiri dalam waktu yang bersamaan.

Ruang yang hadir dalam perjalanan ruang dalam waktu sebagai bentuk ruang fisik. sehingga ruang fisik terjadi dalam waktu tidak untuk memberikan ruang interpretasi sebagai bentuk institusi atau imajinasi. Ruang temporer memang bersifat dinamis tetapi terbentuk dan terkonstruksi secara psikis yang berjalan di masa dengan berdasarkan pada kehadiran faktual. (Heidgger M., 1985).

Ruang dan proses sosial yang terbentuk dari ruang temporal ini dihubungkan oleh implikasi timbal balik. Yaitu adanya ruang dan waktu, adanya tempat dan kesempatan. Menurut Lefebvre, pernyataan ini dapat dengan mudah diambil contoh dari karya-karya Marx yang dikhususkan kritik ekonomi politik. Marx memparkan adanya penyimpangan tradisi historis yang lebih mengutamakan duniawi daripada duniawi dimensi spasial dari fenomena sosial.

\section{METODE PENELITIAN}

Metode Pengumpulan \& Analisa Data, metode pengumpulan data menggunakan 2 jenis metode pengumpulan data yaitu Studi Pustaka Tematik yaitu proses pengumpulan data baik sekunder maupun primer yang hanya dilakukan sebatas kajian pustaka dari berbagai sumber terkait tematik studi awal tersebut. Metode analisa data pada studi awal ini menggunakan analisa tematik dan Analisa Deskriptif.

Analisa Tematik, analisa tematik adalah jenis analisa yang mengkaji dan mengaitkan fenomena sebagai tema penelitian dengan berbagai data yang dikumpulkan dengan metode studi pustaka tematik, analisa ini memfokuskan tema pada fenomena yang dipilih ada studi kasus.

Analisa Deskriptif, metode deskriptif adalah metode dalam penelitian untuk membuat gambaran yang lebih detail mengenai situasi dan kondisi baik subyek maupun obyek penelitian hingga didapat bentuk akumulasi dan pendapat-pendapat pada tiap bahan yang di deskripsikan. Selain itu jenis analisa ini juga tidak hanya memberikan gambaran terhadap fenomenafenomena yang tertematikan, bisa juga bertujuan untuk menerangkan hubungan antar variabel maupun antar substansi penelitian.

Teknik Penarikan Simpulan, teknik penarikan simpulan menggunakan metode deduktif, yaitu metode penarikan simpulan dari simpulan umum menuju kesimpulan yang lebih khusus. 


\section{HASIL DAN PEMBAHASAN}

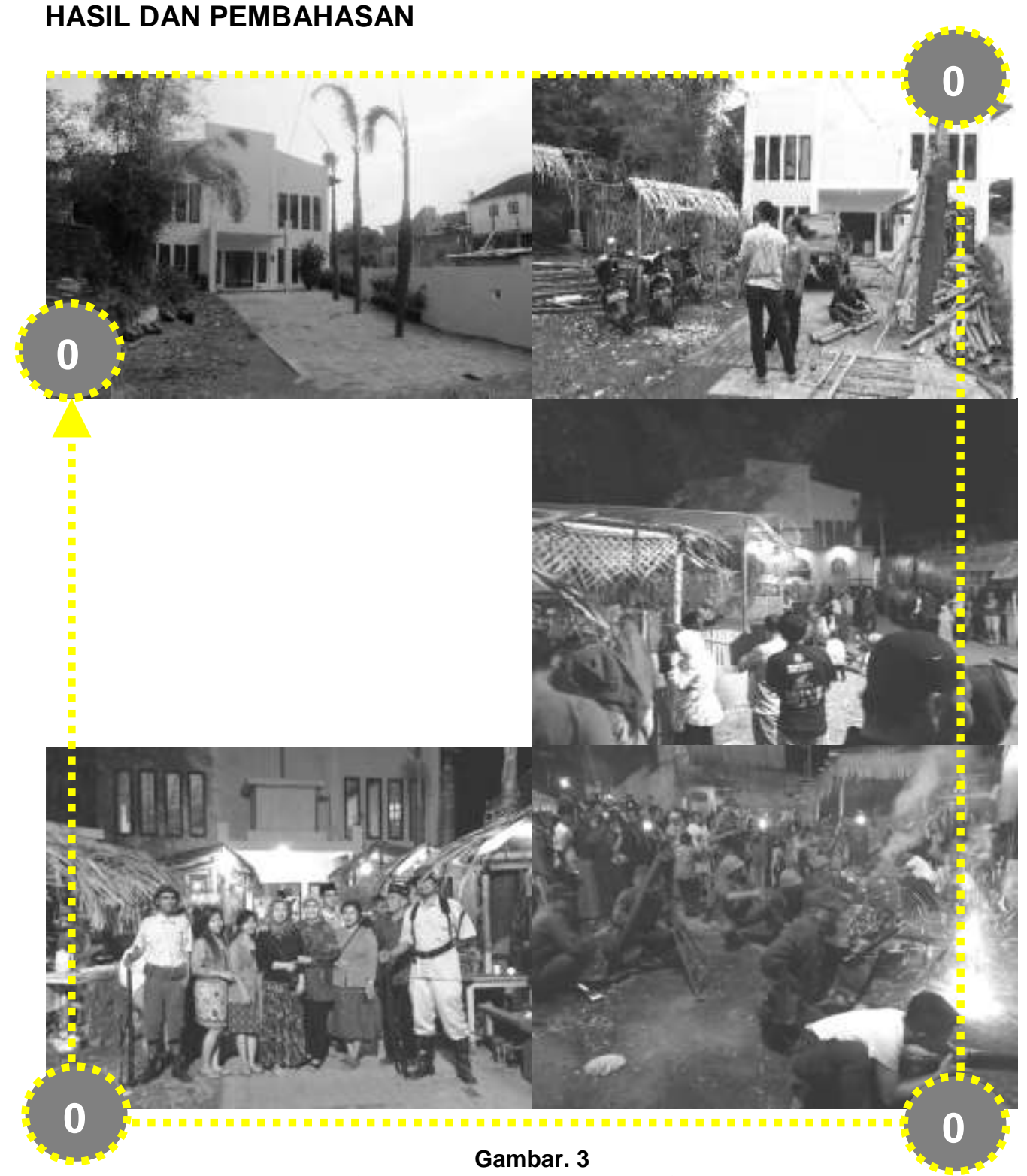

Produksi Ruang Sosial Temporer: Kampung Sedjarah Tawangsari Sumber: dokumentasi dan analisa penulis

Menurut (Putra, 2017) Kelurahan Sumbersari memiliki ragam kultur sosial yang majemuk dan bervarian. Dari kemajemukan tersebut diperlukan sebuah gagasan metode pendekatan forum diskusi guna mewujudkan produksi ruang publik yangh berbasis sosial dalam lomba rancang Malang tahun 2016. Dari gagasan ide masyrakat tersebut terciptalah gagasan desain kampung tematik yang efektif dan sesuai dengan harapan warga Sumbersari.

PAWON: Jurnal Arsitektur, Nomor -- Volume --, Bulan Tahun, ISSN 2597-7636 
Produksi ruang sosial ini berupa festival sedjarah kampung Tawangsari. Dalam (Putra, 2018) metode pendekatan yang digunakan dalam menciptakan festival kampung Tawangsari tersebut menggunakan metode desain partisipatori masyarakat. Melalui pendekatan Partisipatori masyarakat, pengamatan terlibat, dan FGD (Forum Group Discussion) diharapkan mampu memberikan desain ruang publik yang berbasis sosial yang efektif dan sesuai dengan harapan masyarakat setempat.proses produksi ruang sosial melibatkan berbagai pihak antara lain: fasilitator dan tim pendamping antara lain perencana dan akademisi, anggota masyarakat Sumbersari, Re-enactros sebagai embrio sosial masyarakat sumbersari yang peduli dengan sejarah, perangkat desa dari kelurahan Sumbersari dll. Henri Lefebvre dalam "Production of Space" : memaparkan dalam produksi ruang baik itu ruang secara fisik terukur yang direncanakan melalui berbagai proses pengukuran hingga eksekusi guna maupun ruang yang dilihat sebagai ruang "heterotopia" atau ruang imajiner secara non fisik tidak terukur. Semua jenis ruang yang terproduksi dari perancang merupakan ruang yang telah melalui proses produksi. Produksi ruang sosial yang temporer pada studi kasus telah melewati berbagai proses dan berbagai jaringan masyarakat pembentuknya. Teori tentang jaringan masyarakat dalam membentuk ruang sosial berlandaskan beberapa prinsip yang berkaitan psikologi lingkungan antara lain diungkap dalam (Wellman,1983). Prinsip jaringan masyarakat pembentuk ruang sosial ini antara lain:

1. Ikatan antara aktor biasanya adalah simetris, maupun a simetris. Ada ikatan asimetris antara unsur-unsur di dalam sebuah sistem jaringan ruang sosial temporer yang terbentuk. Hal ini diakibatkan bahwa adanya sumber daya manusia sebagai aktor pembentuk ruang yang terbatas. Sedangkan simetris adalah seimbang dalam arti pembentuk ruang sosial ini terbentuk dari jaringan aktor baik dalam kadar maupun identitasnya yang seimbang. Ikatan simetris dalam produksi ruang temporer pada studi kasus dapat dikatakan seimbang, hal ini yang membentuk ruang temporer sosial bersifat formal karena terbentuk secara legal. Festival kampung Sedjarah Sumbersari terbentuk dari adanya festival rancang Malang kampung tematik yang diselenggarakan oleh Pemkot Malang.

2. Ikatan antar individu masing-masing aktor harus dianalisis dalam konteks struktur jaringan yang luas. Pada studi kasus Festival kampung Tawangsari ikatan antar induvidu pembentuk ruang sosial sangat kuat dan terstruktur dengan jaringan yang lebih luas.

3. Terstrukturnya ikatan sosial. Ikatan sosial terbentuk dari berbagai jenis jaringan masyrakat yang majemuk. Sebagai contoh jaringan antar aktor maupun kelompok aktor pembentuk ruang sosial adalah: bila ada ikatan satu aktor A atau kelompok aktor A, maka akan ada ikatan aktor B dan C, ada kemungkinan terdapat juga ikatan antara $\mathrm{A}$ dan $\mathrm{C}$. saling keterikatan jaringan masyarakat antara berbagai lapis pembentuk ruang temporer spasial pada studi kasus ini antara lain: hubungan keterikatan fasilitator dan

PAWON: Jurnal Arsitektur, Nomor 01 Volume IV, Bulan Januari-Juni Tahun 2020, ISSN 2597-7636 
tim pendamping seperti perencana dan akademisi, dengan anggota masyarakat Sumbersari, Re-enactros sebagai embrio sosial masyarakat sumbersari yang peduli dengan sejarah, perangkat desa dari kelurahan Sumbersari dll. Yang saling berhubungan satu sama lain. Dari berbagai lapis aktor pembentuk ruang sosial ini memungkinkan adanya interkorelasi jaringan yang transitif antar pembentuk ruang tersebut. Adanya kelompok jaringan menyebabkan terciptanya hubungan silang antara kelompok jaringan maupun antara individu.

\section{KESIMPULAN}

Space is real in the same sense that commodities are real since (social) space is a (social) product" (Lefebvre 2000:26).

Produksi Ruang Sosial Temporer: Kampung Sedjarah Tawangsari merupakan salah satu bentuk ruang sosial yang terbentuk dari berbagai proses pembentukan ruang. Dalam (Lefebvre 2000:26) proses pembentukan ruang sosial ini juga di dukung oleh jaringan masyrakat pembentuknya. Dalam (Wellman,1983) prinsip jaringan masyarakat dipaparkan menjadi enam ungkapan, dalam studi kasus terpilih terdapat 3 jaringan masyarakat pembentuk ruang temporer spasial antara lain: Ikatan Antar aktor pembentuk yang simetris, ikatan antar individu aktor pada jaringan masyarakat yang lebih luasa dan adanya strusktur ikatan sosial yang terhubung .

\section{DAFTAR PUSTAKA}

Carr, S. (1992). Public Space. New York: Cambridge University Press.

Lefebvre, H. (1996), Writings on Cities, Cambridge, MA." Blackwell.

Lefebvre, H. (2000), A new space for knowledge and people? Henri Lefebvre, representations of space, and the production of 22, Cambridge, MA." Blackwell.

Putra, Ghoustanjiwani.A. dkk. 2017 "Kampung heritage Tawangsari Sumbersari dalam Lomba kampung tematik, festival rancang Malang".

Pawon, 2017. Intitut Teknologi Nasional, Malang

Putra, Ghoustanjiwani.A. dkk. 2019. Kajian Ruang Publik Sebagai Modal Sosial Pembentuk Kohesi Sosial Sebagai Respon Era Industri 4.0

Re-enactor, Ngalam, 2016, Kampung Heritage Sumbersari dalam Rancang Kota Malang, Malang Semsina 2, 2019.

Salès, Lola. 2018. The Street Vendors Act and the right to public space in Mumbai. Mumbai., India: Articulo, Jurnal of urban research: Street vending facing urban policies.

Stevens, Quentin. 2018. Temporary uses of urban spaces: how are they understood as 'creative'?. Melbourne., Australia., Archnet-IJAR: International Journal of Architectural Research. 
Wellman, Barry; Hiscott, Robert. 1983. From Social Support to Social Network. Toronto. University of Toronto, Canada 
